\title{
Analysis of Characteristics of Ore about Iron Deposit of Da Hong Mountain in Yun Nan Province
}

\author{
Zhang Yuefeng ${ }^{1 a}$, LI Jun ${ }^{1}$, Tian Yimin ${ }^{1}$, Yao Yanling ${ }^{1}$, Zhang Yaguang ${ }^{1}$, Ma Mengling ${ }^{2}$ \\ ${ }^{1}$ Faculty of Land and Resource Engineering, Kunming University of science and technology, Kunming, Yunnan \\ ${ }^{2}$ Regional Geology and Mineral Resources Survey Institute of Hebei Province Lang fang
}

\begin{abstract}
This thesis aims to analyse the deposit characteristics about Da Hong Mountains Iron ore in Yunnan province. The texture and structure, especially the chemical composition, is different in every section of deposit after comparing. Moreover, the content of $\mathrm{SiO}_{2}$ is much higher than general iron ore. However, the content of other noble metals cannot reach the lowest industrial grade. Da Hong Mountains Iron ore has unique features because of metallogenic periods.
\end{abstract}

\section{Introduction}

The great red iron ore in Xinping County Yunnan province .It is a large Iron-copperdeposit, a typical submarine volcanic eruption and depositional deposit. There are unique form between different section of mineral deposit with the multiply metallogenic period

\section{Distribution of Ore Bodies in the Mining Area}

According to the distribution of ore bodies 、 output position 、 buried depth 、 tectonic boundaries and other factors. Mining area Can be divided into five ore blocks, that is shallow iron ore、Deep iron ore、No. 1 East of iron-copper、 the north shore of Mangang river and Hamubai group iron.

Shallow iron or: Shallow iron mine is located in the south of Mangang river, the north of $F_{2}$ fault, which exposed surface buried shallow orebody. The main ore body located in more than 700 meters in elevation, it included industrial orebody 30 .

Deep iron ore is located in between F1 and F2 fault location, buried deep blind ore bodies. Most main orebody reserves distributed in below 600 meters in elevation.

No. 1 East of iron-copper is located in between the eastern F3 and the east A49, which contain iron and copper ore bodies.

Mangang River is located the north of the river surface of the exposed surface of the iron ore. The ore body is the same as that in the southern bank of the south bank. The ore body is buried in shallow depth, the depth is not large, the scale is small, and there are 4 industrial ore bodies ${ }^{[1]}$
Hamubai group iron is the ore deposit that is between the easts of A39 line to the A45 Line East Hamubai group stratum. The orebody and the south shore shallow strata are the same horizon, the surface of the scattered, small size, a total of 3 industrial ore body. ${ }^{[2]}$ (photo1)

The main of metal mineral is magnetite, siderite, followed by chalcopyrite. The main of gangue minerals is feldspar, quartz, garnet, biotite, and dolomite. According to the main of metal mineral and gangue mineral is divided into five types: Quartz with brass magnet ore, felsic brass magnet ore, garnet biotite contain brass magnet ore, felsic dolomite with brass magnet siderite mixed ore, felsic dolomite with brass siderite ore.

\section{The Texture and Structure}

Metal mineral is mainly composed of magnetite, followed by hematite, with a small amount of martite (magnetic hematite), ilmenite, pyrite and chalcopyrite, occasionally it can see bornite. Gangue mineral is mainly composed of sodium feldspar, quartz, followed by white mica, carbonate and iron silicate minerals (mainly chlorite). Although the content of apatite and tourmaline is less, but its distribution is broad, and occasionally it can see rutile, zircon, epidote and hornblende, etc.

The main structure of mineral is granular structure, followed by slab structure and lamellar structure. The part of the structure is porphyritic structure, commonly it can see metasomatic texture, and the local of structure is granular clastic texture. The structure characteristic of 


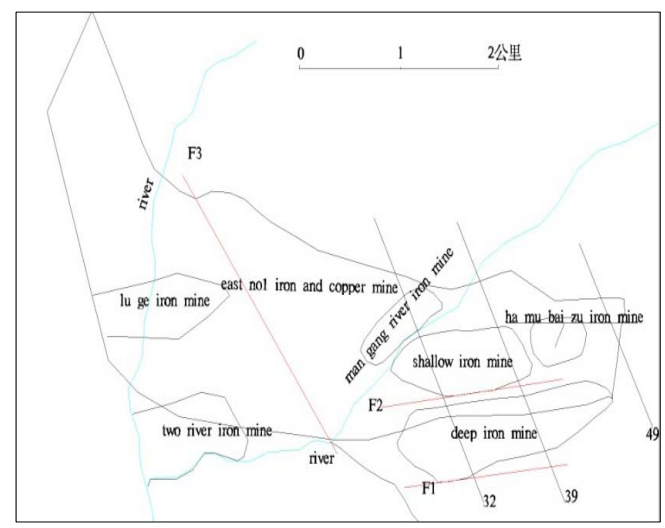

Figure 1 Ore block dividing plane projection draw

Magnetite is granular structure (Figure 2). The structure characteristics of hematite is allotriomorphic granular texture (Figure 3), the structure of hematite also has slab structure and lamellar structure. Magnetite is phenocryst of the mixed ore and the mixed ore has porphyritic structure.Hematite replaces the magnetite, which results the replacement texture,normally it can see that the hematite fills and replaces magnetite particles along its edge, cleavage and fissure, the shape of hematite replaces magnetite is needle, lattice, grid or net vein, and even when magnetite is replaced by hematite, the shape of the residual magnetite seems like an island or all the magnetite is replaced by hematite and appears the illusion of hematite(magnetic hematite); Granular blasted texture is only can be seen in Striped and banded magnet.

The ore structures have various styles. Such as disseminated structure, banding and barred structure, piebald structure, breccia structure, mottling structure, patch structure, massive structure and dense massive structure $^{[3]}$ ( Figure 4、5、6)

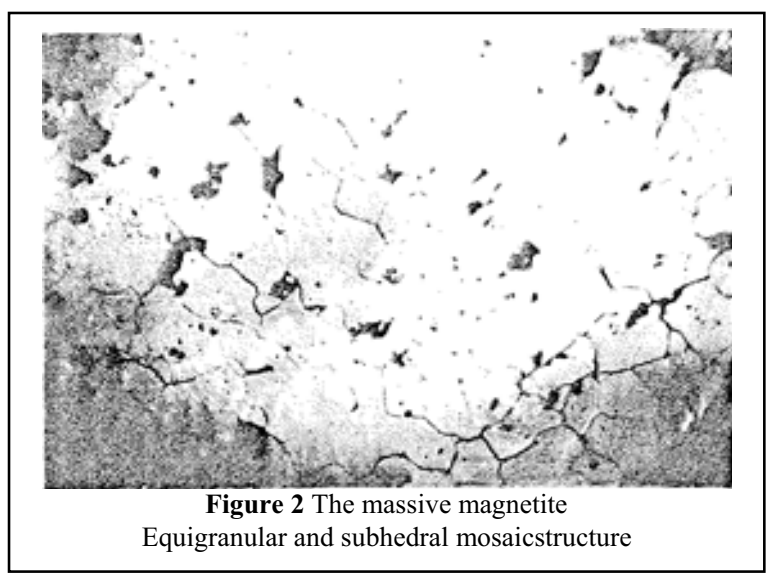

Structure characteristics of the mineral composition and structure of the iron ore bodies and mineralization with common characteristics, But different ore belt iron ore body also has obvious difference. Especially in the deep iron ore more features, that the main metal mineral and gangue mineral, structure, ore types and mineralization, and so on have its own way, making it different from other Iron Orebody

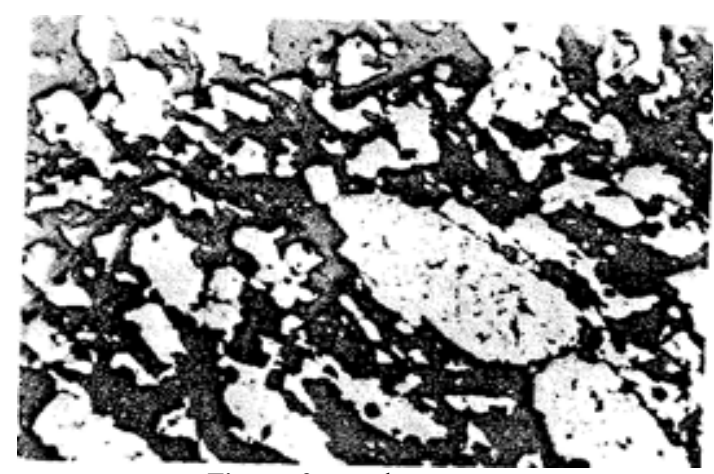

Fi gure 3 granular structure

the white object is hematite, subhedral and anhedral form hematite
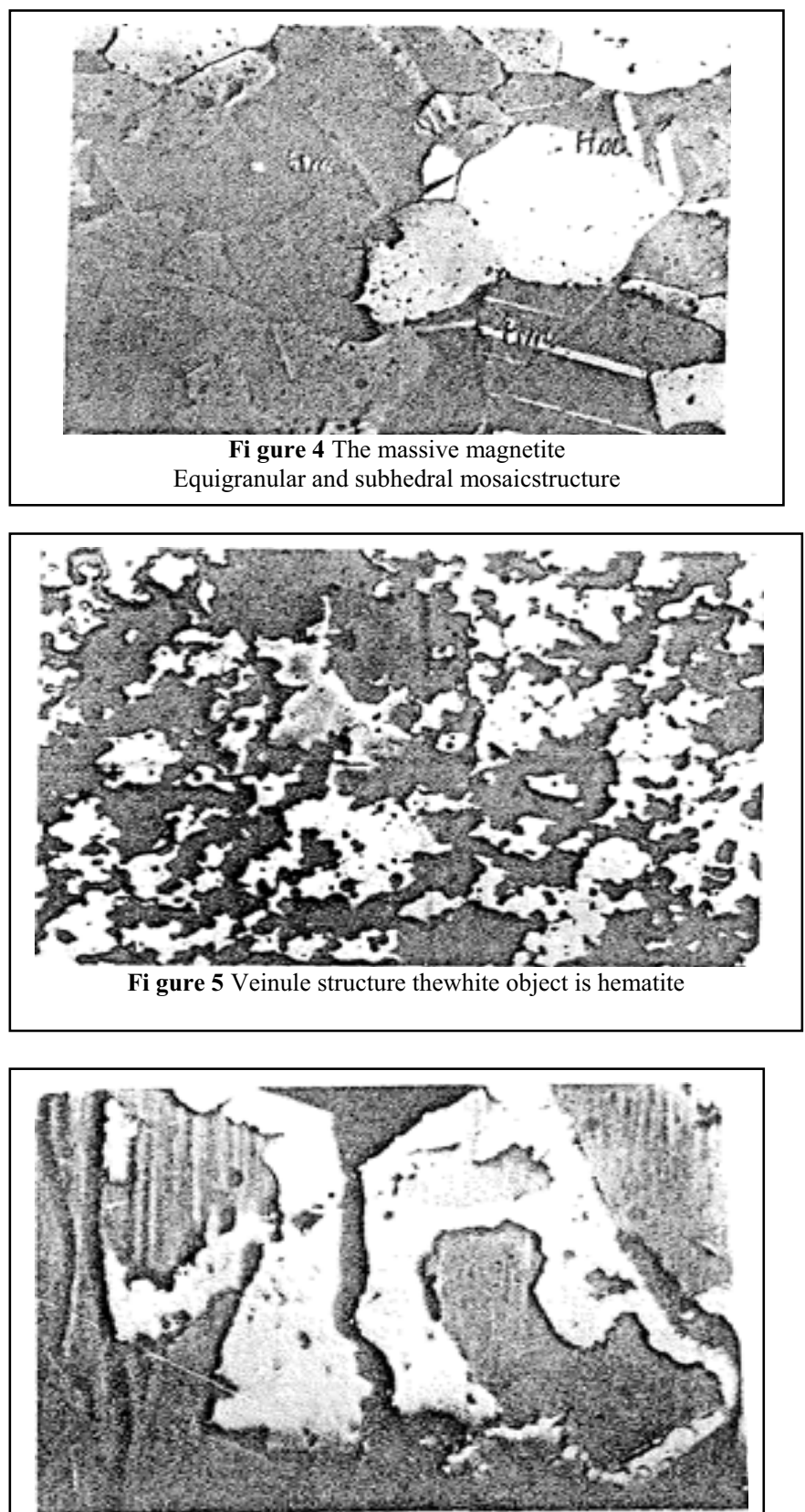

Fi gure 6 metasomatic texture thewhite object is hematite 


\section{Ore chemical composition analysis}

Main element content of different ore block of Iron orebody percentage shown in the following table (1)

Rich iron ore. The scope of TFe is $51.39 \sim 59.08 \%$ the average content of $\mathrm{TFe}$ is $54.71 \%$.poor iron ore, the scope of $\mathrm{TFe}$ is $30.36 \sim 34.90 \%$ the average content of
$\mathrm{TFe}$ is $52.74 \%$.TFe in the second deep orebody is higher than shallow orebody. The content of the Sio 2 in iron ore is usually higher, In Rich iron ore it is $12.49 \sim 24.19 \%$ and the average is about $18.91 \%$.in Poor iron ore the data is $37 \sim 44.55 \%$, the average is $40.60 \%$.

Table 1The main elements content of ore

\begin{tabular}{|c|c|c|c|c|c|c|c|c|c|c|c|c|c|}
\hline \multirow{2}{*}{$\begin{array}{c}\text { Orebody } \\
\text { numbering }\end{array}$} & \multirow{2}{*}{ Ore type } & \multirow{2}{*}{$\begin{array}{c}\text { Ore } \\
\text { level }\end{array}$} & \multirow{2}{*}{$\begin{array}{l}\text { The } \\
\text { num } \\
\text { ber }\end{array}$} & \multicolumn{10}{|c|}{ The main elements content } \\
\hline & & & & TFe & $\mathrm{SFe}$ & $\mathrm{FeO}$ & $\mathrm{S}$ & $\mathrm{P}$ & $\mathrm{SiO}_{2}$ & $\mathrm{Al}_{2} \mathrm{O}_{3}$ & $\mathrm{CaO}$ & $\mathrm{MgO}$ & $\mathrm{K}_{2} \mathrm{O}$ \\
\hline \multirow{2}{*}{ V3 } & \multirow{2}{*}{ Magnetite } & Poor & 5 & 31.33 & 30 & 14. o6 & 0.02 & 0.24 & 40.45 & 4.26 & 2.25 & 1.44 & 0. $\mathrm{O5}$ \\
\hline & & Rich & 1 & 59. 08 & 58.52 & 26.89 & $0 . \mathrm{Ol}$ & 0.14 & 12.49 & 0.76 & 1.76 & 0.65 & 0.05 \\
\hline \multirow{2}{*}{$\mathrm{V} 2$} & \multirow{2}{*}{ Magnetite } & Poor & 15 & 30.36 & 29.03 & 16. 01 & 0.03 & 0.45 & 37 & 8. $\mathrm{O} 3$ & 3.52 & 2.12 & 0.08 \\
\hline & & Rich & 5 & 56.40 & 56.35 & 26.22 & 0.00 & 0.12 & 15.22 & 1.51 & 1.64 & 0.36 & \\
\hline \multirow{5}{*}{ IV $1-1$} & \multirow{5}{*}{$\begin{array}{l}\text { Magnetite } \\
\text { and red- } \\
\text { magnetite }\end{array}$} & $20 \sim 25$ & 1 & 24.15 & 23. O5 & 13.25 & 0.10 & 0.11 & 41.49 & 11.80 & 1. $\mathrm{O} 2$ & 3.40 & \\
\hline & & $25 \sim 30$ & 3 & 28.82 & 28.15 & 7.94 & $0 . \mathrm{O} 3$ & 0.15 & 43.59 & 8.12 & 1.34 & 0.59 & 0.50 \\
\hline & & Poor & 3 & 32.60 & 32.17 & & 0.04 & 0.15 & 44.55 & $3: 56$ & 0.82 & 1. O5 & 0.35 \\
\hline & & Rich & 7 & 51.95 & 50.87 & 23.19 & 0.01 & $\begin{array}{ll}0 . & \mathrm{O} 7\end{array}$ & 24.19 & 0.73 & 1.05 & 0.33 & 0.06 \\
\hline & & $\begin{array}{c}\text { Averag } \\
\mathrm{e}\end{array}$ & & 38.75 & 38.13 & 17.21 & $0 . \mathrm{O} 3$ & 0.13 & 37.90 & 3.90 & 1.18 & 0.81 & 0.32 \\
\hline \multirow{4}{*}{ III1 } & \multirow{4}{*}{ Magnetite } & $20 \sim 25$ & 4 & 22.24 & 21.63 & 11.12 & 0.08 & 0.12 & 40.86 & 11.75 & 2.51 & 1.79 & \\
\hline & & $25 \sim 30$ & 2 & & 28.44 & 10.53 & $0 . \quad$ OO & 0.14 & 40.38 & 7.63 & 1.93 & 0.98 & 1.69 \\
\hline & & Poor & 1 & 34.90 & 32.37 & 11.31 & 0.06 & 0.08 & 41.98 & 3.70 & 2.64 & 0.88 & \\
\hline & & $\begin{array}{c}\text { Everag } \\
\mathrm{e}\end{array}$ & & 25.27 & 24.50 & 1.76 & 0.06 & 0.12 & 40.77 & 8.64 & 2.35 & 1.32 & 1.69 \\
\hline \multirow{5}{*}{ II 1} & \multirow{5}{*}{$\begin{array}{c}\text { Magnetite } \\
\text { and }\end{array}$} & $20 \sim 25$ & 44 & 21.99 & 21.65 & 5.83 & 0.05 & 0.16 & 45.75 & 10.24 & 1.87 & 1.13 & 1.04 \\
\hline & & $25 \sim 30$ & 50 & 27.41 & 27.16 & 5.92 & 0.03 & 0.17 & 45. 03 & 5.83 & 1.74 & 0.63 & 0.61 \\
\hline & & Poor & 51 & 34.53 & 34.24 & 8.96 & 0.02 & 0.17 & 39.01 & 4.34 & 1.77 & 0.61 & 0.48 \\
\hline & & Rich & 174 & 51.39 & 49.96 & 13.77 & 0.02 & 0.13 & 23.73 & 1.26 & 1.19 & 0.44 & 0.09 \\
\hline & & $\begin{array}{c}\text { Everag } \\
\mathrm{e}\end{array}$ & & 39.91 & 39.62 & 10.38 & 0.02 & 0.15 & 30.08 & 3.65 & 1.49 & 0.59 & 0.33 \\
\hline
\end{tabular}


There is an inverse correlation between the content of $\mathrm{SiO} 2$ and TFe, especially in the rich ore usually, the value of $\mathrm{TFe}+\mathrm{SiO} 2$ is a constant (Table 2$)^{[4]}$, which indicates that mineral composition is simple and consist of iron minerals and quartz. For example, enriched iron ore of II lmetallogenic belt, which has a high grade of $\mathrm{TFe}\left(\right.$ more than $55 \%$ ), the value of $\mathrm{TFe}+\mathrm{SiO}^{2}$ is $73.50 \%$. Magnetite with $60 \%$ grade of TFe is consisting of $84.25 \%$ magnetic mineral and $13.50 \% \mathrm{SiO}^{2}$, that means the value of magnetic mineral and quartz is $97.75 \%$. Because lean ore has other minerals like albeit and other silicate, the law is not as regular as rich ore.

Table 2 relationship between different grade ore $\mathrm{TFe}$ and $\mathrm{SiO}_{2}$

\begin{tabular}{|c|c|c|c|c|}
\hline $\begin{array}{l}\text { Grade } \\
(\%)\end{array}$ & $\begin{array}{l}\mathrm{TFe} \\
(\%)\end{array}$ & $\begin{array}{l}\mathrm{Si02} \\
(\%)\end{array}$ & $\begin{array}{c}\mathrm{TFe}+\mathrm{Si} 0 \\
2 \\
(\%)\end{array}$ & For note \\
\hline 65 以上 & 66.71 & 5.73 & 72.44 & As $\mathrm{TFe}$ is $55 \sim 65 \%$ \\
\hline $60 \sim 65$ & 62.46 & 10.90 & 73.36 & $\begin{array}{c}\text { TFe60.06\% } \\
\text { Si0213.94\% }\end{array}$ \\
\hline $55 \sim 60$ & 57.73 & 16.97 & 74.70 & \multirow{2}{*}{$\mathrm{TFe}+\mathrm{Si} 02=74 \%$} \\
\hline Average & 62.30 & 11.20 & 73.50 & \\
\hline
\end{tabular}

$\mathrm{MyO}, \mathrm{CaO}$ :The content of $\mathrm{CaO}$ and $\mathrm{MgOis}$ low in the Iron orebody, The content of $\mathrm{CaO}$ usually is $1.53 \sim 2.51 \%$, The highest content of the Cao is $7.61 \%$, The lowest levels of the $\mathrm{Cao}$ is $0.65 \%$ and the average content is $2.39 \%$; The content of MyO usually is $0.59 \sim 2.50 \%$ and the average content is $1.34 \%$ 。 The content of $\mathrm{CaO}$ in Late Palaeozoic basin of the first and third ore-group and the average content is $4.04 \%$, The content of MyOis relatively high Iron Orebody, The content of $\mathrm{MyO}$ usually is $1.5 \sim 4.5 \%$ and the average content is $3.38 \%$.The content of Different grades and different types Iron Orebody changed little, irrelatively stable.

Acid-base Ratio: Thanks to the content of $\mathrm{CaO}$ and $\mathrm{MyO}$ are low however, Sio2 is high, the Acid-base Ratio of Iron Orebody is small. The ratio of major Iron Orebody is $0.04 \sim 0.15 \%$. They belong to the acidic ore. ${ }^{[5]}$ The ratio of Different grades, different types Iron Orebody changed little and there are the trends of the ratio decreases change low with The decline of ore grade. By the magnetite and hematite ratio from large to small (table3).

Table 3 II $_{1}$ Acid-base Ratio

\begin{tabular}{|c|c|c|c|c|c|c|}
\hline \multirow{2}{*}{ Ore type } & \multirow{2}{*}{$\begin{array}{l}\text { TFe } \\
(\%)\end{array}$} & \multicolumn{4}{|c|}{ slaggingcomponents $(\%)$} & \multirow{2}{*}{$\frac{\mathrm{CaO}+\mathrm{MgO}}{\mathrm{Si}_{2}+\mathrm{Al}_{2} \mathrm{O}_{3}}$} \\
\hline & & $\mathrm{CaO}$ & $\mathrm{MgO}$ & $\mathrm{Si02}$ & $\mathrm{Al}_{2} \mathrm{O}_{3}$ & \\
\hline $\begin{array}{c}\text { Rich } \\
\text { magnetite }\end{array}$ & 55.01 & 1.18 & 0.56 & 19.46 & 1.19 & 0.084 \\
\hline
\end{tabular}

\begin{tabular}{|c|l|l|l|l|l|l|}
\hline $\begin{array}{c}\text { Red- } \\
\text { magnetite }\end{array}$ & 45.14 & 1.48 & 0.45 & 31.76 & 1.88 & 0.057 \\
\hline $\begin{array}{c}\text { rich } \\
\text { Red- } \\
\text { magnetite }\end{array}$ & 40.60 & 1.13 & 0.38 & 32.47 & 4.12 & 0.041 \\
\hline $\begin{array}{c}\text { rich } \\
\text { Red- } \\
\text { magnetite }\end{array}$ & 50.62 & 1.02 & 0.33 & 24.84 & 0.83 & 0.052 \\
\hline $\begin{array}{c}\text { Poor } \\
\text { magnetite }\end{array}$ & 34.10 & 1. & 0.83 & 36.33 & 5.88 & 0.062 \\
\hline $\begin{array}{c}\text { Poor } \\
\text { Red- } \\
\text { magnetite }\end{array}$ & 37.75 & 2.17 & 1.14 & 29.88 & 5.65 & 0.093 \\
\hline $\begin{array}{c}\text { Poor } \\
\text { magnetite }\end{array}$ & 27.78 & 1.13 & 0.43 & 46.09 & 6.14 & 0.029 \\
\hline $\begin{array}{c}\text { Roor } \\
\text { magnetite }\end{array}$ & 30.95 & 0.96 & 0.20 & 46.35 & 3.53 & 0.023 \\
\hline
\end{tabular}

\section{Beneficial Associated component content and Occurrence state}

Through the combination of analysis, artificial placer, optional test, in a single iron ore body was not found with comprehensive utilization value of accompanying useful components, but in the I 、 III ore $\mathrm{Au}$ 、 $\mathrm{Ag} 、 \mathrm{Co} 、 \mathrm{Pt}$ 、 Pd can be integrated recovery, Its content is shown in table 1-4. From table (4) ore grade is low, no separate recovery value, but it can get in sulfide concentrates after beneficiation different degree of enrichment, that can consider to comprehensive recovery.

Gold, silver: IN ore belt iron copper ( I 3、 I 2) $\mathrm{Au}$ 0.08 and $0.11 \mathrm{~g} / \mathrm{t}, \mathrm{Ag} 0.53$ and $0.63 \mathrm{~g} /$ due to the run of mine ore content with little, $\mathrm{Au}, \mathrm{Ag}$ are not found in mineral alone. But we can get in sulfide concentrates after beneficiation good enrichment. This description Au, $\mathrm{Ag}$ occurrence in sulphide minerals easy for comprehensive recovery. The distribution of its distribution is obviously related to the $\mathrm{Cu}$, namely when the $\mathrm{Cu}$-rich, $\mathrm{Au}, \mathrm{Ag}$ content is also relatively increased.

According to the III copper ore analysis the mineral sample, $\mathrm{Au} 0.33 \mathrm{~g} / \mathrm{t}, \mathrm{Ag}, 2.6 \mathrm{~g} / \mathrm{t}$. According to the selected 18 sample test results show that the copper concentrate in $\mathrm{Au}$ enrichment cannot get enrichment, but it can get enriched in iron concentrate. 
Table 4 Copper associated components

\begin{tabular}{|c|c|c|c|c|c|c|c|c|c|c|}
\hline \multirow{2}{*}{\begin{tabular}{|c|} 
Oreb \\
ody \\
num \\
berin \\
$\mathrm{g}$
\end{tabular}} & \multicolumn{5}{|c|}{ head grade ( $\mathrm{g} /$ ton) } & \multicolumn{5}{|c|}{ concentrate grade( $\mathrm{g} /$ ton $)$} \\
\hline & $\mathrm{Au}$ & $\mathrm{Ag}$ & $\operatorname{Co}(\%)$ & $\mathrm{Pt}$ & $\mathrm{Pd}$ & $\mathrm{Au}$ & $\mathrm{Ag}$ & $\begin{array}{l}\mathrm{Co}( \\
\%)\end{array}$ & $\mathrm{Pt}$ & $\mathrm{Pd}$ \\
\hline I 3 & 0.08 & 0.53 & 0.012 & 0.00 & 0.01 & 1.62 & 11 & $\begin{array}{c}0.02 \\
7\end{array}$ & $\begin{array}{c}0.03 \sim \\
0.09\end{array}$ & 0.14 \\
\hline I 2 & 0.11 & 0.63 & 0.012 & 0.00 & 0.02 & 1.69 & 13 & $\begin{array}{c}0.05 \\
94\end{array}$ & $\begin{array}{c}0.03 \sim \\
0.09\end{array}$ & 0.17 \\
\hline III & 0.33 & 2.60 & 0.006 & 0.00 & $\begin{array}{c}0.01 \\
2\end{array}$ & 0.28 & $\begin{array}{c}12.8 \\
4\end{array}$ & $\begin{array}{c}0.04 \\
5\end{array}$ & 0.00 & 0.02 \\
\hline
\end{tabular}

Co: No.1ore containing Co generally not less than $0.01 \%$, average $0.012 \%$. Sulfide concentrate containing Co $0.027 \sim 0.0594 \%$, compared with about five times ore enrichment, different types of ore concentrate containing Co are quite different taste, marble-type ore is higher, up to $0.514 \%$; Biotite schist type ore is low. Cobalt in class in the sulfide mass with like and adsorption state, mainly because some of the iron cobalt replace when entering the pyrite lattice, so the value of the lattice parameters of pyrite increases

\section{Conclusions}

1.From rock slice, original rock of ore district can be deduced as mafic-intermediate volcanic rocks, which was obviously affected at hydrothermal alteration from early time, some rocks got regional metamorphism later.

2.Big red mountain iron ore is a kind of magmatic eruption - sedimentary hydrothermal deposit, which suffered metamorphism during the ore-forming process. Especially, the mineralization of ore is obviously at the ore enriched zone.

3.There is an inverse correlation between the content of $\mathrm{SiO}_{2}$ and $\mathrm{TFe}$, especially in the rich ore. Usually, the value of $\mathrm{TFe}+\mathrm{SiO}_{2}$ is a constant

4. The content of $\mathrm{CaO}$ and $\mathrm{MgO}$ is poor and stable, and it doesn't change a lot at different grade and types of iron ore.

5.Except the content of $\mathrm{Au}$ and Ag for parts of No.1 or3 mine can reach the grade of pay utilization; other ore can't reach the grade. Moreover, though Au can't enrich at the copper concentrate, Au can enrich at the iron concentrate. It's a new question waiting for further research.

\section{References}

1. Li Shengrong. Crystallography and Mineralogy. Geological Publishing House.2008.in China

2. McSween H. Y, Murchie S. L, Crisp J. A, et al. Chemical, multispectral, and texturconstraints on the composition and origin of rocks at the Mars Pathfinder landing site[J].Journalof Geophysical Research Atmospheres, 1999, 104(E4):8679-8715.

3. WangHunxun, HeChunshan. About the test procedure and method of grinding. nonferrousmetals, 1980, (6)in China

4. Zhaole. Identifying correlation of iron grade and silicon dioxidecontent in iron- mineral concentrate using regression analysis[J]Metallurgical Standardization \& Quality2006,(44)17-21 in China

5. Ying-chieh Lee, Wei-HuaLu, et al. Influence of $\mathrm{SiO}_{2}$ Addition on the Dielectric Properties and Microstructureof Ceramics[J]. International Journal of Applied Ceramic Technology, 2009,(6):692-701. 